\title{
Delayed presentation of traumatic left hemidiaphragm rupture in a child
}

\author{
Ewa Matuszczak, Wojciech Dębek \\ Department of Pediatric Surgery, Medical University of Bialystok, Poland
}

Kardiochirurgia i Torakochirurgia Polska 2013; 10 (3): 289-292

\begin{abstract}
The authors present the case report of a 6-year-old girl admitted to the ICU after being knocked over by a car. The girl had an extensive wound of the hypogastric area - a soft tissue injury that required surgery. Ultrasound (US) of the abdominal cavity, CT of the head, and X-ray examination of the chest, spine, and abdomen did not reveal any signs of internal organ injuries or bone fractures. The wound was closed in layers. Control CT of the head, US of the abdomen, and X-ray of the chest were normal. On the $6^{\text {th }}$ day, the patient's general condition deteriorated. Chest X-ray with a nasogastric tube showed a loss of the left diaphragmatic outline and a large gastric shadow occupying the left hemithorax and displacing the mediastinum to the right. A left-sided traumatic diaphragmatic rupture with gastrothorax was diagnosed. The patient was immediately operated on. The girl made an uneventful postoperative recovery.

Conclusions: Careful interpretation of the chest radiograph and early surgical intervention are likely to yield good outcomes in patients with posttraumatic diaphragmatic rupture and diaphragmatic hernia. All patients with possible diaphragm damage and recurrence of pulmonary dysfunction or intestinal symptoms (such as obstruction, nausea, and pain) should be investigated for posttraumatic diaphragmatic hernia.
\end{abstract}

Key words: diaphragmatic hernia, diaphragmatic rupture, trauma, children.

\section{Introduction}

The diaphragm is the major muscle of ventilation. Its rupture presents a challenging emergency, because it can be missed during trauma diagnosis. Pressure difference between the thorax and the abdomen allows the abdominal viscera to herniate into the chest cavity. Cardiorespiratory and abdominal symptoms may appear later, due to passive compression and incarceration. The aim of this article is to present a case involving a delayed presentation of a trau-

\section{Streszczenie}

Autorzy prezentują przypadek 6-letniej dziewczynki przyjętej na Oddział Intensywnej Opieki Medycznej z powodu urazu jamy brzusznej, po potrąceniu przez samochód. Przy przyjęciu stwierdzono rozległą ranę podbrzusza bez naruszenia ciągłości otrzewnej. Badanie ultrasonograficzne (USG) jamy brzusznej, tomografia komputerowa (TK) głowy oraz badanie rentgenowskie (RTG) klatki piersiowej, kręgosłupa i jamy brzusznej nie uwidoczniły urazów narządów wewnętrznych. Ranę zaopatrzono warstwowo w warunkach bloku operacyjnego. Kontrolna USG jamy brzusznej, TK głowy i RTG klatki piersiowej nie wykazały zmian pourazowych. W 6. dobie pobytu stan dziecka gwałtownie się pogorszył; RTG klatki piersiowej z sondą żołądkową uwidoczniło żołądek przemieszczony do klatki piersiowej, powodujący przesunięcie śródpiersia. Dziecko było operowane w trybie pilnym. Przebieg pooperacyjny był niepowikłany. Wnioski: U wszystkich pacjentów po urazach jamy brzusznej, u których nawet po dłuższym czasie od urazu występują objawy duszności oraz zaburzenia pasażu w przewodzie pokarmowym, należy wykonać diagnostykę w kierunku pourazowej przepukliny przeponowej.

Słowa kluczowe: przepuklina przeponowa, pęknięcie przepony, uraz, dzieci.

matic rupture of the left hemidiaphragm and subsequent diaphragmatic herniation in a 6-year-old child.

\section{Case report}

A six-year-old girl was admitted to the ICU in grave general condition with impaired consciousness and symptoms of traumatic shock after being knocked over by a car. The girl had an extensive wound extending from the left lumbar area across the hypogastrium to the right ingui-

Address for correspondence: Ewa Matuszczak, Department of Pediatric Surgery, Medical University of Bialystok, Waszyngtona 17, 15-274 Białystok, tel. +48 608430 844, e-mail: ewamat@tlen.pl 
nal area. The left tibia was fractured at $1 / 2$ of its length. Immediately after admission, the patient was intubated and placed on mechanical ventilation. No signs of internal organ injuries were visible during the US examination of the abdominal cavity. CT of the head and X-ray examination of the chest, spine, and abdomen likewise did not reveal any signs of internal organ injuries or bone fractures. Laboratory tests confirmed the presence of signs of anemia and microhematuria. After the hemorrhagic shock was controlled, the patient was moved to the operating theatre. In the course of the operation, avulsion of the abdominal muscles from the left iliac ala to the right pubic bone was noted, but the peritoneum and the wall of the urinary bladder were not ruptured. The wound extended from the left renal capsule to the right iliac fossa. A small hematoma was evacuated from the perirenal fat capsule. The wound was closed in layers and the fractured limb was repositioned. The results of control CT of the head, US of the abdomen and X-ray examination of the chest were similar to the initial results. The general condition of the patient improved. Broad-spectrum antibiotics were administered. On the second day, the endotracheal tube was removed, and on the third day oral fluids were commenced. During the following days, the diet was broadened and respiratory rehabilitation was started. On the $6^{\text {th }}$ day, the girl's general condition deteriorated. She suddenly developed difficulty breathing, dull aching central chest pain, and palpitations. The girl was in severe respiratory distress, hypotension, and tachycardia (heart rate: 180/min). General cyanosis and reduced chest movement were observed. Auscultation of the lungs revealed a significant reduction of the vesicular murmur, especially on the left side, together with signs of mediastinal displacement to the right. The chest X-ray (Fig. 1) was interpreted by intensivists as showing pyopneumothorax, and the left pleural cavity was immediately drained. Drainage of the left pleural cavity was placed in the $2^{\text {nd }}$ intercostal space in the anterior axillary

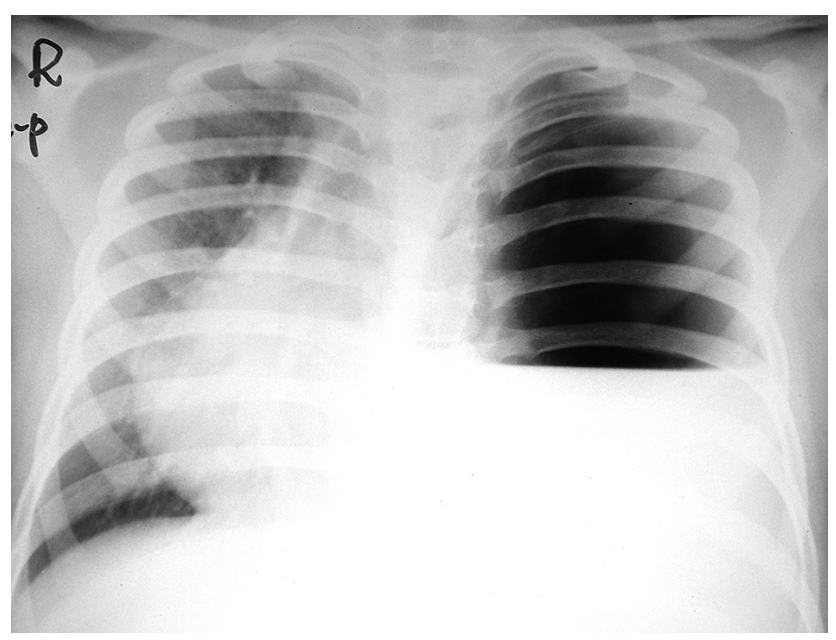

Fig. 1. Chest X-ray - performed on the $6^{\text {th }}$ day after admission when the general condition of the girl deteriorated - pleural effusion line. Small amounts of air and a yellow-brown substance were obtained. Another urgent frontal and lateral chest X-ray with a nasogastric tube (Fig. 2) showed a loss of the left diaphragmatic outline and a large gastric shadow occupying the left hemithorax and displacing the mediastinum to the right. A diagnosis of a missed left-sided traumatic diaphragmatic rupture with gastrothorax was made. The patient was immediately operated on. An upper midline laparotomy incision was used to access the abdominal cavity, where a rupture $(6 \times 3 \mathrm{~cm}$ in size $)$ was noticed in the left dome of the diaphragm, along with herniation of the stomach, greater omentum, and part of the ileum. After the reduction of the abdominal viscera, the diaphragmatic defect was closed in two layers using vicryl 2-0 sutures: the first layer employed interrupted sutures, and the second used continuous sutures. The surgery was completed by draining the left pleural cavity. The drains were removed on the next day after the surgery. The girl made an uneventful postoperative recovery; chest $\mathrm{X}$-ray examination, performed immediately after the operation, showed intraabdominal relocation of the stomach and a well-defined diaphragmatic outline (Fig. 3). Spontaneous bowel movements occurred on the second postoperative day. The patient commenced oral intake on the $3^{\text {rd }}$ post-operative day and was discharged home on the $31^{\text {st }}$ day after admission.

\section{Discussion}

Posttraumatic diaphragmatic hernia is a displacement of internal abdominal organs to the chest cavity through a pathological aperture in the diaphragm due to trauma [1]. Acquired diaphragmatic hernias usually occur after motor vehicle accidents, falls, stabs, or after laparoscopic upper abdominal surgery [2]. Diaphragmatic hernias in children usually pose a diagnostic challenge; their presentation is varied and may include acute abdominal pain with features of gut obstruction, pleuritic chest pain, and breathlessness. The diagnosis of posttraumatic diaphrag-

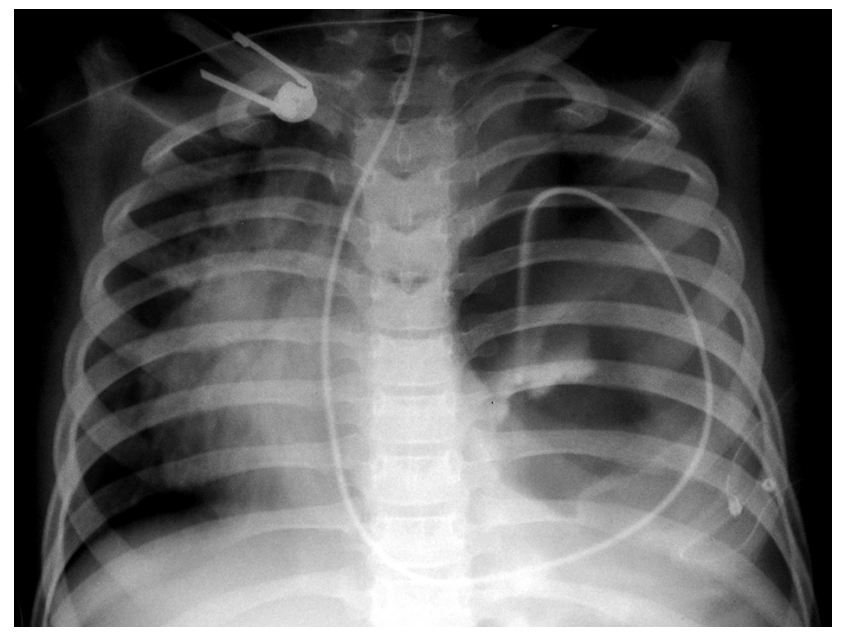

Fig. 2. Frontal chest X-ray with a nasogastric tube - loss of the left diaphragmatic outline, large gastric shadow occupying the left hemithorax and displacement of the mediastinum to the right 
matic hernia is often delayed, especially if the existence of diaphragm damage is not established during the acute period of the trauma $[1,3,4]$. In patients with penetrating abdominal injuries, the diagnosis of posttraumatic diaphragmatic hernia is usually made intraoperatively; therefore, both hemidiaphragms must be inspected during any exploratory laparotomy for trauma $[4,5]$. Unnoticed diaphragmatic ruptures inevitably result in herniation of the abdominal contents into the chest, due to the intraabdominal-to-intrathoracic pressure gradient, and cause sudden deterioration of the patient's general condition. Displaced abdominal viscera exert pressure on the lung, heart, and great vessels, which may result in reduced venous return to the heart and diminished cardiac output [6]. The stomach is the most common organ that herniates through diaphragmatic rupture, due to its proximity to the relatively unprotected left dome of the diaphragm $[6,7]$. Because the stomach is a gas-containing organ, its herniation into the chest may be indistinguishable from tension pneumothorax, as was the case with our patient. Misdiagnosis may result in tragic consequences [8]. Acute diaphragmatic rupture is recognized in $0.8-7 \%$ of patients with blunt abdominal trauma, and in $10-15 \%$ patients with penetrating abdominal trauma $[9,10]$. About $90 \%$ of diaphragmatic ruptures occur on the left side, as was the case with our patient [6]. The left posterolateral aspect of the diaphragm is a structurally weak area because it originates from the pleuroperitoneal membrane. The right diaphragm is congenitally stronger than the left, and is partially protected by the liver, which can dissipate pressure over a large area [10, 11]. Although injury of the right hemidiaphragm occurs less frequently than injury of the left side, more severe injuries are associated with right sided ruptures, which result in greater hemodynamic instability $[6,10,11]$. According to the literature, mortality rates vary from $1 \%$ to $28 \%$ depending on the associated injuries. A mortality rate of $30 \%$ has been found in cases of bowel strangulation associated with diaphragmatic hernia [12]. Common associated injuries include pelvic fractures (40-55\%), splenic injuries (60\%), and renal injuries [11-13].

Many investigative techniques for the diagnosis of posttraumatic diaphragmatic hernia have been described, including chest X-ray, CT scan, magnetic resonance imaging, upper Gl contrast studies, angiography, ultrasonography, thoracoscopy, peritoneal lavage, and laparoscopy [5]. Initial chest radiographs miss up to half of diaphragmatic ruptures presenting to the emergency department [11-13]. In our case, an X-ray performed with a nasogastric tube (which would be considered standard of care) or with a chest tube would have made the diagnosis self-evident. CT of the chest is diagnostic in $30-50 \%$ of cases [10]. Most patients with posttraumatic diaphragmatic rupture complain of dyspnea and pain in the upper abdomen, but generally present with symptoms related to their associated injuries. Auscultation of bowel sounds in the chest, as well as tympany or dullness on percussion of the chest, should arouse suspicion of diaphragmatic rupture [14].

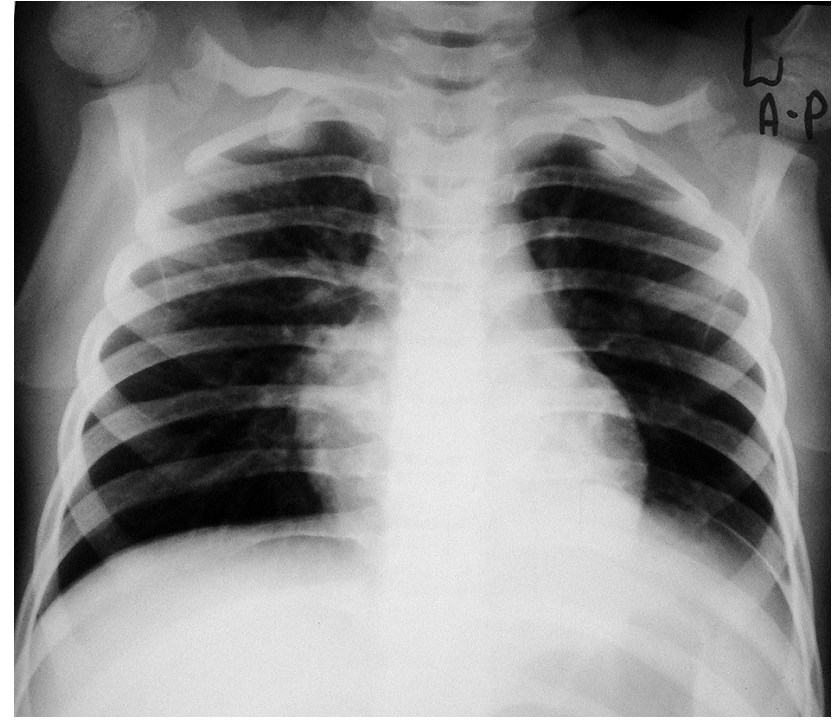

Fig. 3. Chest X-ray after surgical intervention - intra-abdominal relocation of the stomach and well-defined diaphragmatic outline

Results of the surgical treatment depend on the severity of the pathological changes in the diaphragm and the surrounding organs [1]. Surgical access to the site of the diaphragmatic rupture is dictated by the associated injuries and the time interval between the injury and the diagnosis. Abdominal access is preferred in acute trauma which may involve associated intraabdominal visceral injuries; in the case of delayed presentations of diaphragmatic hernia (more than 6 weeks), thoracotomy is usually performed because it provides much easier access for separating adhesions between the involved abdominal viscera and the lungs and repairing the diaphragmatic defect [11, $13,14]$. In our case, an upper midline laparotomy incision enabled us to fully assess the stomach.

\section{Conclusions}

Careful interpretation of the chest radiograph with a contrasting gastric tube and early surgical intervention are likely to yield good outcomes in patients with posttraumatic diaphragmatic ruptures and diaphragmatic hernias. The history of traumatic events should be considered with high suspicion during the diagnostic process to avoid delayed diagnosis of this condition. All patients with possible diaphragm damage and recurrence of pulmonary dysfunction or intestinal symptoms (such as obstruction, nausea, and pain) should be investigated for posttraumatic diaphragmatic hernia.

The authors declare no conflicts of interests.

\section{References}

1. Crandall M, Popowi|ch D, Shapiro M, West M. Posttraumatic hernias: historical overview and review of the literature. Am Surg 2007; 73: 845-850.

2. Kao Y, Lee WJ, Lin HJ. Tension gastrothorax: a lifetrheatening cause of acute abdominal pain. CMAJ 2009; 180: 983. 
3. Galimberti A, Casagrande A, Compagnoni BM, Sansonetti G, Rusconi A, Grassi M, Ferrante F. Late post-traumatic diaphragmatic hernia: unusual cause of colonic occlusion. Chir Ital 2001; 53: 551-554.

4. Lee WJ, Lee YS. Traumatic diaphragmatic rupture: a diagnostic challenge in the emergency department. Emerg Med J 2007; 24: 601.

5. Haciibrahimoglu G, Solak O, Olcmen A, Bedirhan MA, Solmazer N, Gurses A. Management of traumatic diaphragmatic rupture. Surg Today 2004; 34: 111-114.

6. Gwely NN. Outcome of blunt diaphragmatic rupture. Analysis of 44 cases. Asian Cardiovasc Thoracic Ann 2010; 18: 240-243.

7. lochum S, Ludig T, Walter F, Sebbag H, Grosdidier G, Blum AG. Imaging of diaphragmatic injury: a diagnostic challenge? Radiographics 2002; 22: 103-116

8. McCann B, O'Gara A. Tension viscerothorax: an important differential for tension pneumothorax. Emerg Med J 2005; 22: 220-221.

9. Meyers BF, McCabe CJ. Traumatic diaphragmatic hernia. Occult marker of serious injury. Ann Surg 1993; 218: 783-790.
10. Boulanger BR, Milzman DP, Rosati C, Rodriguez A. A comparison of right and left blunt traumatic rupture. J Trauma 1993; 35: 255-260.

11. Turhan K, Makay O, Cakan A, Samancilar O, Firat O, Icoz G, Cagirici U. Traumatic diaphragmatic rupture: look to see. Eur J Cardiothorac Surg 2008; 33 1082-1085

12. Reber PU, Schmied B, Seiler CA, Baer HU, Patel AG, Büchler MW. Missed diaphragmatic injuries and their long-term sequelae. J Trauma 1998; 44: 183-188.

13. Simpson J, Lobo DN, Shah AB, Rowlands BJ. Traumatic diaphragmatic rupture: associated injuries and outcome. Ann R Coll Surg Engl 2000; 82: 97-100.

14. Mihos P, Potaris K, Gakidis J, Paraskevopoulos J, Varvatsoulis P, Gougoutas B, Papadakis G, Lapidakis E. Traumatic rupture of the diaphragm: experience with 65 patients. Injury 2003; 34: 169-172. 